\title{
The Role Of Technical Know-How In Determining The Legal Nature Of A Franchise Contract
}

\author{
Dr. Mohammed I Abu El-Haija \\ School of Law, Middle East University, Amman H.K of Jordan
}

doi: 10.19044/esj.2016.v12n1p190 URL:http://dx.doi.org/10.19044/esj.2016.v12n1p190

\begin{abstract}
In view of the importance of a franchise contract in disseminating knowledge, and improvement, this study came to shed light on technical knowledge and its impact on determining the legal nature of a franchise contract. It also illuminated the possibility of the existence of a weak idea or a compliance problem in this type of contract. Strengthening of concession contracts was recommended, particularly relating to the industrial sector, which would inevitably lead to development and prosperity.
\end{abstract}

Keywords: Franchise, Technical know-how, Knowledge

\section{Introduction}

The basic pillars or the real motive of franchise is improvement. These pillars spur the drive for more technical knowledge which leads to increased number of studies to develop expert knowledge on legal and economic phenomena. Recent contracts have demonstrated an important element, which is a key focus on technology when it comes to the nature of these contracts. Generally, the cornerstone of a franchise contract is the object of that contract. Furthermore, until the approval of the contract, the licensee needs to exploit the knowledge underlying the franchise because it imposes conditions often licensed to the licensee.

There are several definitions of franchise. One is, "a contract which allows or permits a producer or a trader to emulate another dealer using the right methods of sale and service given by the donor" (Radwan, F, 1988, p. 15).

Another is a contractual relationship between the licensor and licensee, whereby the licensor transfers know-how and training to the licensee who performs the work under supervision. However, this is done using a form or procedure owned or controlled by the licensor. Here, the licensee invests his own money in the licensed work to the success or failure of the process (Al-bishtawi D, p. 20). 
It goes without saying that there is no single agreed definition of franchise. However, franchise is considered the theme of complex modern distribution systems of technical products and services or manufacturing materials and products. It gives the distinguishing mark of a trademark owner or a supplier to other distributors (the licensee) to use exclusively, including franchise commercial brand name and, sometimes, patents and technical skills. This is all done under supervision as well as commercial and technical support in order to distribute the products and services of a supplier or manufacturer. However, these services and products are then marketed and sold to a third party within the specified geographical area and for the duration of the contract.

In our view, franchise can be defined as a contract in which the licensor gives the licensee the right to use one or more industrial and intellectual property rights or know-how for the production of goods. Franchise is also seen as the distribution of products or services through the exclusive use of a licensor-owned brand in a specific geographical area and within a specified duration of time, under his supervision and adhering to his instructions. Furthermore, the licensor often provides technical assistance in return for agreed ends.

\section{Importance of the Study}

The study finds importance in its analysis of the transfer of technical know-how and its role in development and prosperity on the one hand. In addition, it also shows the conditions under which authorized licensors can transfer technical know-how to licensees.

\section{Problem and Study Questions}

The problem stems from the study of the role licensors play in the imposition of conditions on the licensee regarding the transfer of technical know-how. However, an important question that arises with respect to the extent of the imposition of conditions by the licensor is, will licensees comply? The important implications of this question allow the court of law, if the answer is yes, to intervene and abolish such conditions.

\section{Methodology of the Study}

This study will follow an analytical approach through the analysis of legal texts and jurisprudence understudy on the impact of technical knowhow on determining the legal nature of franchise contracts.

\section{Structure of the Study}

To answer the question raised above, we will approach this study from two parts. The first part will address the concept of technical know- 
how, while we will devote the second part to dealing with its impact on franchise contracts.

\section{The concept of technical know-how}

The term 'know-how' is a legal term which was used under contracts of technology transfer in the first one-third of the twentieth century. Then, it connoted expansion and phased deployment, lasting until the mid-twentieth century (Nasir A, p. 277). Now, it is understood to be the transfer of technology based on the idea of patent holders (professionals) for the purpose of establishing industrial units and increasing the productivity of patents in developing countries. However, the term does not exclude the 'means of development' meaning, bearing in mind the difficult items included on patent rights. Moreover, it raises an important question with respect to the meaning of technical know-how and its distinctive characteristics.

\section{Definition of Technical Know-how}

There are two schools of thoughts in jurisprudence concerning the definition of technical know-how, namely the narrow trend and broad technical knowledge trend. This disadvantages the concept because it blurs the notion of know-how and because of the lack of the presence of a special, independent legal regime within the legal systems (Abdul-Zaher $\mathrm{M}$ ).

\section{A Long Narrow or Technical Concept}

This concept suggests the idea of being confined within the limits of knowledge, technical know-how, and techniques in the industry and manufacturing processes, without extending to other areas. One definition is that it is the set of elements that give artistic skill, technical and administrative expertise, and specific industry oriented styles and art industry.

In another definition, it is applied knowledge for using industrial techniques and putting them into practice (International Chamber of Commerce).

However, another defines it as a set of practical knowledge and experience accumulated in unit production over time and learned by trial and error in the application of abstracted technological knowledge to the production process. This knowledge has value, and it is clear that technical know-how or technical sense is, in fact, a scientific knowledge and is embodied in three factors, namely: the production unit, the brains, and the hands (Almawla N, p. 37).

The American court adopted this definition, when its Supreme Court's ruling considered the right definition of technical know-how. Know- 
how is a new secret in the industry, stretching back to the stage of manufacturing and also information and associated tests (referred, Nasir, op.cit, p. 279).

During the French led trend, the Appeals Court "Duway" said of technical know-how in 1967 to be: "industrial secret meaning distinct from the idea of invention; secret feature concerning a set of actions of particular importance; and significance of know-how means applied technology.”

In another ruling by the same court in 1969, technical know-how consisted of the total technical information and technical issues concerning the application of a particular procedure or industrial stage and a must-have for all these new properties and good information on what preceded it" (AlKilani M, 2008, p. 72-74).

From all the previous definitions, technical know-how can be identified along the narrow concept as a collection of information, knowledge, and techniques related to the industrial and manufacturing processes.

\section{Legal Concept or Broad Technical Knowledge}

In legal terms, technical know-how means all technical information representing the technical enrichment of the knowledge of a narrow circle of people (Nasir A, op.cit, p. 279).

The definition reflects the characteristics of this kind of knowledge. Technically, it represents beneficiation, which means it is new and is confined to a specific category of people, creating confidentiality.

In another definition, "technical information is shown to have two advantages. First, it is confidential, and second, it gives preference to rivals" (Almawla N, op.cit, p. 38).

As defined, it is a set of technological knowledge, practical management, and new industrial transmission which keep, secret, projects not covered by patents" (Eisa H, 1982, p. 130).

In another definition, it is any information or experience relating or not relating to information within a patent (Alhani S, p.212).

Thus, industrial exploitation is not a synonym for invention. Rather, it is independent and yet, at the same time, it is coupled with it, and there is no contradiction between them. Therefore, this limits the patent to the description of the invention and the statement of specifications. The patent does not show labour exploitation regarding the prevailing technical situation, nor does it give an idea of implementing competence. Consequently, it achieves technological application for invention of any practical application in industry, which in and of itself is technical know-how or knowledge of manufacturing. 
This meaning has been taken for technical knowledge by some international conventions and national legislation as well as by the jurisprudence. The committee has identified the protection of industrial property by the International Chamber of Commerce's 1972 definition of technical know-how: "the term 'skill know-how' extends to the body of knowledge and experience not only for the practical application of certain techniques, but also for industrial and commercial exploitation by management and financial institutions” (Alowfi S, 1998, p. 42).

I took the direction of the international convention concerning aspects of intellectual property rights (TRIPS) by specifying the requirement to protect confidential information. This occurred after the reports indicated technical knowledge, as stated in article 19/2: "natural and moral persons' right to prevent disclosure of information under lawful control of or access to or use of them without their consent in a manner contrary to honest commercial practices." When verifying such information, the following conditions ensue:

- Confidentiality: it is not, in its entirety, in a form or assembly of components commonly known or easy to get by people, usually among the dealers in that type of information.

- $\quad$ Commercial value: commercial value stems from confidentiality.

- $\quad$ Being subjected to reasonable steps to keep it within the person's legal control under current conditions.

The nation recalled the Jordanian legislature's situation when it became biased as a result of using competition law and trade secrets No. 15 of 2000. The convention text in article 4a states that any information is trade confidential if:

- $\quad$ Its final form or components are unknown and it is not easily created or manufactured by dealers in this type of information.

- $\quad$ It has commercial value because it is confidential.

- The right holder carries out reasonable measures to maintain confidentiality under current circumstances.

In judicial practice, American justice adopted a broad concept of know-how in certain provisions, including a ruling by the Fourth Circuit Federal court in the United States in 1956 in the Colgate case. Since it introduced the concept of trade secrets within the scope of know-how, the concept came in connection with trade secret as follows: "may be in the form of composition, machine, or a set of information that is used by someone in his work, giving him a certain advantage in the face of rivals who may not know or, at least, use it." Trade secret may be in the form of a specific chemical composition, or specific manufacturing method, model, velocities, or list of customers (referring, Nasir A, op.cit, p. 281). 
Here, we find that the broad concept of know-how accommodates all industrial, commercial, administrative, and financial areas, unlike the narrow concept which is confined to the industrial side only. We also find that those who say that this concept is based on statement and characteristics in order to establish a legal framework for shaping the idea have expanded their concept. This is because of the understanding that, unlike patents, technical know-how does not receive legal protection and hence are at risk.

Although this trend links technical know-how to industrial and commercial secrets, there is a difference between them. Hence, technical know-how is characterized by transition property and widespread circulation. The reverse is the case for industrial secrets.

Giving the broad concept and the narrow concept, we find that there is a negative side to the two concepts. Narrow concept works to limit the notion of technical know-how in manufacturing only. On the other hand, the broad concept includes industrial, commercial, administrative and financial areas, resulting in endangerment because they do not enjoy legal protection, unlike patents.

In our view, technical know-how can be defined as the total industrial, commercial, and management expertise that is transferred in a confidential manner and within agreed terms between the licensor and the licensee within the franchise contract.

\section{Advantages of Technical Know-how}

Based on the preceding definitions, it can be said that technical know-how enjoys a series of advantages and features as follows:

\section{Originality}

In the area of technical knowledge, novelty or originality means that it is generally unknown in the industry, whether developed or not. It may be based on knowledge elements borrowed from an existing technician mode and added for practical improvements or in specific, detailed, and measured ways. Notwithstanding, it renewed the technological level of impact compared to what is existing in other projects (Al-Kilani M, op.cit, p.134).

So, originality was seen in previous cases when we added new values to the receiver, giving him an advantage over his rivals. Moreover, this feature was not up to par, not without the expenses and extraordinary efforts.

With reference to the different concept of originality in technical know-how posted on patents, novelty or originality means patents and novelty not previously disclosed or used by third parties. It also includes never-before spread or broadcast experience or knowledge of others prior to that request claiming priority by written or oral means, which is not considered a patent (Samawi R, 2008, p. 283-289). 


\section{Confidentiality}

Any licensed franchise has experience in the field or in a particular field and are extending beyond working methods or technical means used (Moghabghab N, 2006, p. 91). This is done ensuring that everything is created rightly and delivered to competitors or the public. Either absolutely or relatively, secrecy is involved in technical know-how; and to the relative secrecy protection both in terms of subject matter and persons (Mohammadain G, 2004). Moreover, it is not only limited to standard confidentiality and people who know about it, but also extends to involve genuine creation (Najjar M, 2007, p. 4).

\section{Modernity}

It means to be new and inaccessible by the recipients of the privilege of the contract. If such new knowledge is not provided to the licensee, it is grounds for the nullity of the franchise contract. It also entails a failure of the condition of legitimacy, which is to provide technical knowledge and important feature of modernity to the recipients of the franchise. This condition reflected in the judgment of the French Court of Cassation, which stated that, "the lack of access of the recipient when carrying out the contract for any new or innovative technical knowledge leads to consideration of the contract and do not force..." (Referring to Shammari A, Online publication).

Noteworthy is the standard of verifying the existence of this requirement in professional knowledge. It is a subjective standard, meaning that the concession recipients of the study have knowledge of the elements of know-how, but cannot take advantage of them. However, with the help of a licensed franchise, property of modernity is present in this case as long as the licensed concessionaire combines elements of know-how, writing them, employing them, and then submitting to the licensee the privilege of using them.

\section{Subjective and Flexible}

As the knowledge component of the license, capital money and legal aspects make a great and effective development as one of the tools used by the Chairperson in featuring a wide property move. Therefore, technical know-how is available for transfer without transfer of holders. In addition to scalability, technical know-how transfer is subjective. Subjective knowledge means it is specified accurately in the concession contract in terms of content and how recipients of this knowledge utilize them. Also, it is specified in a statement outside the concession contract provided that the agreement between the licensor and the licensee has been given in this statement, which is included as part of the contract. Hence, this property requires an inventory 
of licensed components of technical knowledge, statement, and applied techniques employed. In addition, it also determines what they are (ibid).

Giving its importance, this property was enshrined in article 1, paragraph 3, of the rules of the European Commission, which confirmed of endogenous technical know-how that such knowledge would be described with sufficient and accurate manner. Therefore, this makes it easier to be used by recipients.

\section{The nature of a franchise contract}

Technical know-how occupies a very important place in a franchise contract, where technical knowledge with a brand is replaced by a franchise contract. The motive of the licensor licensing to the licensee is the success of professional knowledge. Therefore, the purpose of a franchise contract or any other contract for that matter is to establish the mark, which is balanced between supports. However, when talking about a franchise contract, terms have tended to benefit licensed concessionaires at the expense of the licensee's interest because of the success of the technical know-how, the socalled restrictive conditions.

One of the main reasons for restrictive clauses between the licensor and licensee needed for the exploitation of technical know-how is the absence of legislative regulation of franchise contracts in several countries, including Jordan. Therefore, this encourages the licensor to impose restrictive conditions on the licensee, which are not rejected because of the licensee's need for the technical know-how, technology, and brand as noted above. These are in the possession of the licensee for his/her market success and fame, which makes the licensee weak. Furthermore, the licensee is exploited by the licensor as a party economically strong, which could no doubt upset the balance of contractual relationship, which inevitably tends to the benefit of the licensor. These conditions are:

The licensee's obligation to purchase the necessary machinery, equipment, and raw materials necessary for production, plus parts from the licensor or one of its projects. This condition may be justified if the reason for its existence is to ensure the optimal use of technology and thus ensure the quality of the final product. But these disappear if those materials and machinery are available on the market at competitive prices.

- $\quad$ Prevention of the licensee from conducting research about the product in order to develop or improve it. This view was originally in the financial and technical interests of the licensor. Naturally, according to the ordinary course of things that prevents the licensee from conducting such research and studies, it also gives him/her the right to prosecute and seek compensation for any assault on the rights to the technical know-how. Since any further study by the licensee can lead to improvement or development, 
we do not agree with this condition. This is because it contravenes evolution and improvement, which is aimed at development and which is the basis of franchise contracts and technical knowledge.

Development of quantitative restrictions on the volume of production or distribution areas. The license stipulates that the production volume must not exceed a certain amount. Also, the distribution thereof must be limited to the geographical area or territory of a particular state. There are also export bans, wholly or partly, to a particular state. This will, no doubt, inspire the licensee to work harder so as to achieve greater profits, which benefits the licensor even more (Alsagheer H, 1993; Al-bishtawi S, op.cit, p. 74-109). We support this condition that the licensor has the right to choose the markets to be invested in. He also has the right to choose more than one licensee to operate in the same territory or in several regions.

Refusal to renew the contract. The case arose with the question of the eligibility of recipients of license for compensation as a result of the nonrenewal of contracts, especially since he has invested huge funds in the project which will continue for many years (Jabber A, 2005, p. 81-82). In spite of the reasons mentioned by owners of this opinion, we contradicted them by the fact that we only desired to renew or not to renew the contract license granted by the legislator for contractors "pacta sunt servanda." Therefore, we cannot oppose a party-used right granted by law.

This caused some to say that technical know-how is a form of compliance contract, which is the contract offered under prescribed conditions established by the other party, and does not allow for discussion concerning goods or facilities necessary to be a legal monopoly or be a limited debate (Alsaddah A, 1946, p. 76-77). In another definition, it is a contract composed without previous discussion of terms and conditions between the parties, which convinces the project party to offer consent for the contract (Ahmed SH, p. 50).

The Jordanian legislature has defined compliance by the main criterion stated in the acceptance or rejection of the offer without the possibility of negotiation. Article 104 of the civil code enacted the following: "Acceptance in compliance contracts simply delivers under prescribed conditions established by positively accepted debate.” By extrapolating the previous definitions, we can say that if the licensee is deprived of discussing the terms and conditions of the contract, restricting him/her to only accepting or rejecting the above authorized, we no doubt find the root of a compliance issue. However, this argument would be correct if the licensor adheres to certain conditions which interest him, especially if he enjoys economic power and licensed technicians. Furthermore, this would allow him to impose his conditions, causing the licensee to accept these conditions due to 
the need for knowledge, skills, and techniques that have sought to achieve its own interests by exploitation. This view finds support in the following:

- The balance of economic forces of parties sometimes tends to the foreign party. The contracting state is superior in terms of organization, funding sources, and technological capabilities. The licensee (the host state) is economically dependent on the State (receiving), which possesses the power to set limits for such control and restrictions on access to the ultimate goal of achieving a balance between the interests of the parties.

The examination of the relationships on the ground reveals that few contracts contain restrictions on negotiation. Any foreign party not binding on the contract is restricted, unless the same contract abides by State conditions (Jamal Aldin S, 2004, p. 267-268).

The present effort is geared towards bypassing the obstacle of whether or not compliance know-how transfer contracts save time and effort. It is also focused on the proliferation of similar industries and restriction of inadequate legislation status, resolving all legal problems relating to contracts. In particular civil and commercial contracts, the subject matter on technicalities or technology evolves very quickly and could not pursue legislation. This evolution and the standardization of legal rules that govern financial transactions advocated the drafting and modeling of franchise contracts. Hence, this forms the basis of the argument of people who accept the wording of their contracts.

This means that the written format contains general rules and conditions that determine the effects of the deal as well as its provisions in general (Abdul-Zaher M, 2002, p. 11-12). Any showing of the rights and obligations of the support and trade groups have resorted to putting these formulas into use to facilitate trade in certain commodity or group of commodities. This is a step towards reaching a unified contract with all branches of network, which is necessary in order to ensure coherence of formal function. Although the license form refused to adopt inconsistent items from the proposed standardized form, it is still our opinion that the interest of the licensee remains as the basis for moving this contract. This therefore weakens the idea of compliance in this type of contract.

\section{Conclusion}

In conclusion, we illustrated the important role played by technical know-how in determining the legal nature of a franchise contract. Is it compliant or not? Compliance is due to rights held by the licensor, who may refuse to negotiate clauses and conditions of contract. Thus, the study proposed a set of conclusions and recommendations. 


\section{Results}

- $\quad$ Franchise contracts are important for the dissemination of technical knowledge and play an important role in industrial and commercial development.

- $\quad$ Despite the difference in determining the legal nature of the franchise contracts between compliance and equality, the study believes that the contract remains closest to equality. The fact is that the party who worked hard to obtain the technical know-how has the right to enjoy financial and development benefits. Thus, he determines for the licensee the method to use these efforts.

The substantive scope of expertise includes branches of economic activity, production and distribution services, and technical know-how and confidentiality. Furthermore, they add a new economic value to the holder. Confidentiality remains essential to the completion of the legal architecture and the right to make them subject to exclusivity and legal protection.

- $\quad$ Legislative regulation of franchise contracts in Jordan is absent.

\section{Recommendations}

- $\quad$ Franchise contracts should be encouraged, especially those relating to the industrial sector, for the exchange and transfer of technical know-how as well as for development and prosperity.

- $\quad$ The model contracts for grain and cotton should be drafted based on a model contract for franchise contracts.

- Jordanian legislature must interfere through enacting specific acts that deal with the rights and obligations of the parties of the franchise contract. The recommendation based on Article 117 of the Jordanian Constitution, which states all concession granting a right for the exploitation of mines or minerals or public utilities shall be sanctioned by law.

\section{References:}

Ahmed SH. Contract compliance. Master thesis, Faculty of law, Al-nahrain University, 2000.

Al-bishtawi D. Franchise contract and its effects. Master, An-Najah National University, Palestine.

Jaber A. Brief technical development contracts. Al halabi publications, 2005. Jamal al-Din S. Technology transfer contracts, studying under private international law, international trade law. Dar Al-fikr, Alexandria, 2004.

Alsuraihi E. The franchise contract signed mail, http://www.faculty.ksu.edu.sa/dr.essam-alghamdi/.

Samawi R. Patents in the pharmaceutical industry, House of culture publishing, 2008. 
Shammari A. Know-how transfer in the framework of international trade, on the website http://law.uokerbala.edu.iq/index.php/art/125-differentarticles/558-dr-adel-shemran-artc1

Elsadda E. Compliance contracts in Egyptian law. Fouad I University Press, 1946.

Alsagheer H. License to use trademark, Cairo, 1993.

Radwan F. Holding a commercial license/Hussein press (Cairo), 1990.

Abdul Zahir M. The legal aspects of the contract phase, without a Publisher, 2002.

Alofi S. The legal principles in the formulation of international trade contracts, Institute of public administration, 1998.

ISA H. Technology transfer, a study on the legal mechanisms of international dependency, Cairo, 1987.

Kilani M. Banking and commercial encyclopedia, volume I, international trade contracts in the area of transfer of technology, 2008.

Mohammadain G. Legal protection of industrial property, the new University, 2004.

Mustafa S. Technology supply contracts disputes through arbitration. Master thesis, Middle East University, 2009.

Moghabghab N. Franchise, a study in comparative law, human rights, AlHalabi, Beirut Lebanon, 1st, 2006.

Almawla N. The legal implications of technology transfer contracts. Wael publishing, Jordan, without years of publication.

Nasir A, et al. Technical knowledge or impact in franchise, on the site http://www.isaj.net/iasj?func=fullext\&aId=32339.

Alnajjar M. Franchise contract, study on transfer of know-how, Dar Aljalaa, 2007.

Alhani S. Concise in industrial and commercial property, Dar Al Furqan, Jordan. 